UDC 616.314-071-073.7

Kuroiedova V.D., Vyzhenko Y.Y., Makarova O.M., Stasiuk O.A.

\title{
SCIENTIFIC JUSTIFICATION OF THE USE OF CONE-BEAM COMPUTERIZED TOMOGRAPHY (CBCT) FOR CEPHALOMETRIC ANALYSIS IN THE «AUDAXCEPH» PROGRAMM
}

\author{
Ukrainian Medical Stomatological Academy, Poltava, Ukraine
}

An X-ray investigation as additional method of investigation is the main stage in diagnostics and orthodontic treatment. An X-ray allows us the studying of facial skeleton and its correlation with soft tissues, it helps us to define the treatment plan, make diagnosis, study changes.

Such investigations are called roentgenography and cephalometry. Cephalometry is the part of anthropometry, one of the main methods of investigation in anthropology and medicine, in particular in dentistry, including different sizes of man's head [1]. It was done by Pacini in 1922. The author proposed to perform the radiograph from the distance of $2 \mathrm{~m}$, approximating X-ray film to the image. So, an X-ray tube of the apparatus was taken from image on distance, this method was called "teleroentgenogram" (TRG).

In 1931 B. Broadbent in USA and H. Hofrath in Germany proposed standard methods to receive lateral images of the head with the use of an X-ray apparatus and tube adapter for head fixation which was called cephalostat.

In orthodontics among traditional methods of diagnostics OPT (orthopantomography) and TRG are also used [2].

TRG is an X-ray method of the investigation which is characterized by increase of the distance between an X-ray tube and film $(1,5-2 \mathrm{~m})$, at placing cassette charged with film to the head of the patient. Due to this absorbed radiated dose decreases and three dimensional deviations of received image also decrease. However, image on the film reaches to real one and there are three dimensional deviations which are connected with conic placement of beam of non-parallel X-ray and it leads to increase of image and also different distances of different regions of the right and left sides head from the film.

TRG is an additional method for the investigation in orthodontics, orthopedic dentistry, maxillafacial surgery, which is required for diagnostic data and received with examination and study of diagnostic models of jaws.

Due to this method, peculiarities of the shape and structure of facial skeleton are defined, different ways of jaws position, their width and growths of facial skeleton are also determined. This method helps us to differentiate anatomical variants and dif- ferent types of malocclusion, it helps us to determine location of abnormalities or deformities and also study the correlation of soft tissues with facial skeleton. International classification of malocclusion of WHO (1989) supposes to use roentgenographic and cephalometric analyses in diagnostic aims, so the $1^{\text {st }}$ and $2^{\text {nd }}$ types of abnormalities present anomalies of the width and position of jaws in the skull and can be viewed without this diagnostic method.

Besides, to get objective information about changes of facial region of the skull connected with its growth or treatment can be only performing the procedure of application of copies of teleroentgenogram done in different temporary intervals.

Head's rotation or incorrect positioning can be a sign of different deviations. Covering of tissue structures on lateral film causes the deviations in anatomical points on an X-ray pattern, and it is the main source of mistakes in cephalometry [3].

Traditionally, trace and calculation of this procedure was manually done. Such disadvantages prompt to search for new methods and planning for orthodontic treatment [4].

The appearance of computer technologies made a revolutionary burst in doctor's practice and also orthodontists. Computer and modern technology of images allow significantly increasing and modernizing the process of calculation of this procedure.

New methods of X-ray diagnostics such as computer tomography and its type cone-beam computerized tomography were appeared in modern dentistry. CT in orthodontics investigates diagnostic possibilities in impaction cases, dental malposition, anodontia, dental implants, diagnostics and treatment of congenital abnormalities and also allows diagnosing of maxillo-temporal joint $[5,6,7]$.

The first attempts of CT and 3D reconstructions used for cephalometric measurements were described in 1970 [8].

Three-dimensional calculation contains the measurement a distance of points from the skull to main dimensions - medial saggital, front facial and upper facial dimensions. Any point on the skull can be correspondingly evaluated to dimensions [9].

The main drawbacks of cephalometric analysis are high price and high radiation exposure. The de- 
crease of high radiation exposure is one of the main principles for orthodontic patients because major part of them is presented by children. In such cases, all risks and advantages should be considered [10].

If we speak about radiation exposure for the patient it will lower than the dose of another traditional investigation [11]. At average cone-beam exposure contains $50-80 \mu \mathrm{Sv}$. Acceptable dose in 2500 times is higher and it contains $200000 \mu \mathrm{Sv}$. So, the radiation exposure is not significant in comparison with acceptable dose.

Cephalometry has such advantages as sizes of image fully correspond real sizes, geometric deviations and fusion of anatomical structures during forming of 3D image are absent; control of correct positioning cephalometric points is done immediately from 4 windows on the monitor; the ability of computer correction of positioning of head in the space; high quality of images; ability to get several diagnostic images: (teleroentgenogram in lateral projections, orthopantomography, images of temporomandibular joint in different dimensions) [12].

However, in modern scientific literature one algorithm of points distribution on $3 \mathrm{D}$ reconstructions received from CBCT has not been found.

So, the aim of our investigation was to develop the algorithm of distribution of main cephalometric points on 3D reconstructions, received from CBCT and compare measurements done on classic teleroentgenogram and 3D reconstructions.

\section{Materials and methods}

Classic teleroentgenogram were done on the apparatus "MORITA X800», CBCT was done on "VATECH PAX-ZENITH 3D» with software EZ3D2009. In order to compare these methods, the main angular skeletal saggital parameters (SNA, SNB, ANB, SN-Ba), vertical (ML-NSL, NL-ML, Facial axis, $<G)$ and dental $(+1 / \mathrm{NL},-1 / \mathrm{ML},+1 /-1)$ were taken. The analysis of images was done in the program for cephalometry «AudaxCeph». 20 patients were involved in the investigation.

The algorithm of points' distribution on 3D reconstructions

Due to CBCT one can get the image of the head in 4 windows which are called Coronal (it corresponds to frontal dimension), Sagittal (it corresponds to saggital dimension), Axial (partitions in horizontal dimension) and correspondingly 3D.

Before the beginning of points' distribution, it is necessary to perform centering. Saggital line should be passed through the centre of the head through the suture of occipital bone and nasal septum. And, in saggital window axial axis should be parallel to Frankfurter plane.

On medial and saggital section one can put points: N, S, Ba, A, B, Pg, Me (Figure 1).

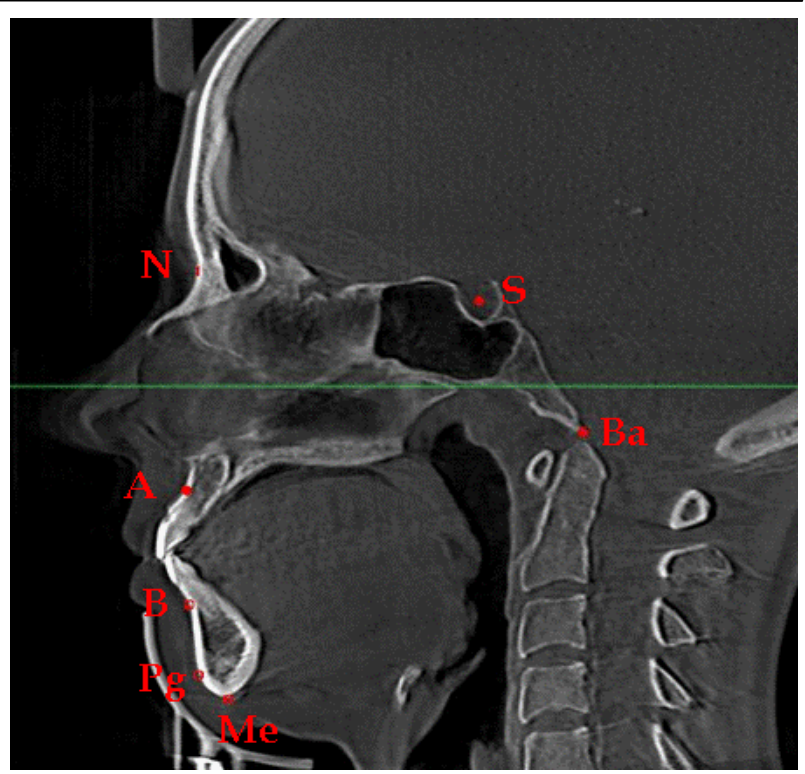

Figure 1. Points' distribution $\mathrm{N}, \mathrm{S}, \mathrm{Ba}, \mathrm{A}, \mathrm{B}, \mathrm{Pg}, \mathrm{Me}$.

Points ANS and PNS should be put on axial section, controlling their location in saggital window (Figure 2).

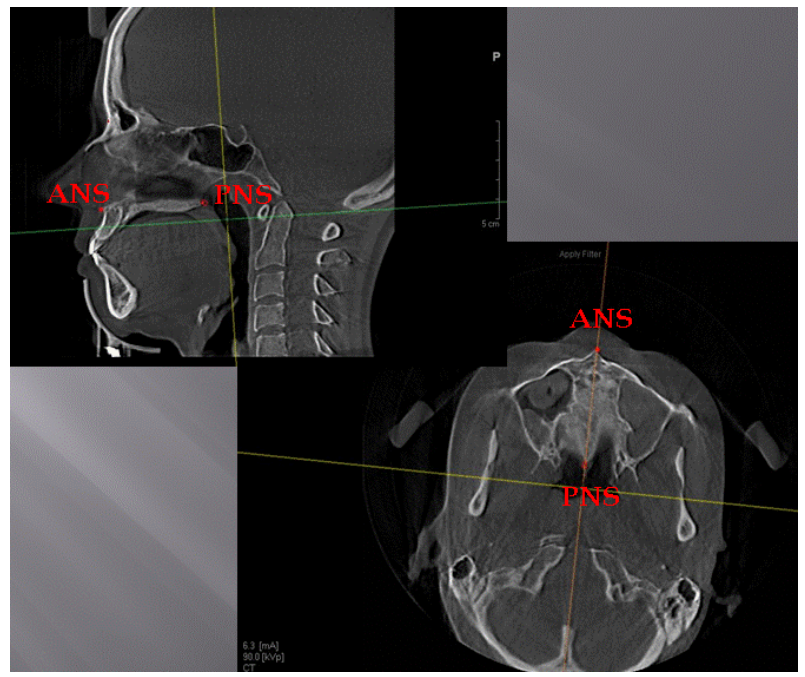

Figure 2. Points' distribution ANS and PNS.

Points of incisors are put on saggital sections, controlling the correct position on other ones. For this, it shifts laterally for more distinct visualization along the all length of central incisor (Figure 3).

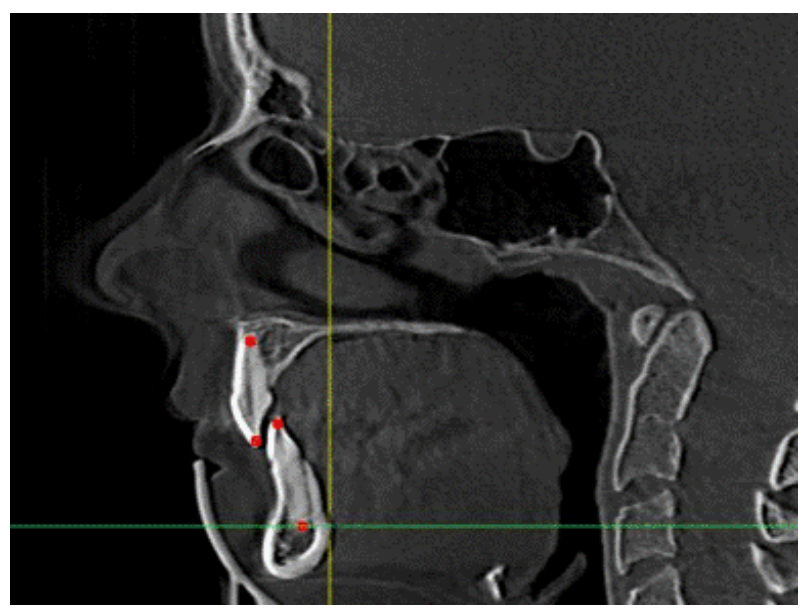

Figure 3. Distribution of incisor points. 
Pt (Pterygoid) point is interesting for algorithm. By topography and anatomy it is situated on the anterior angle of round opening - foramen rotundum. Through round opening from cranium there is maxillary nerve the second branch of trigeminal nerve. In order to find point $\mathrm{Pt}$ on saggital section it is necessary to displace axial axis laterally before the fissure is appeared such as fissura pterygomaxillaris. Radiographically, point Pt is situated on the section of fissura pterygomaxillaris and foramen rotundum (Figure 4).

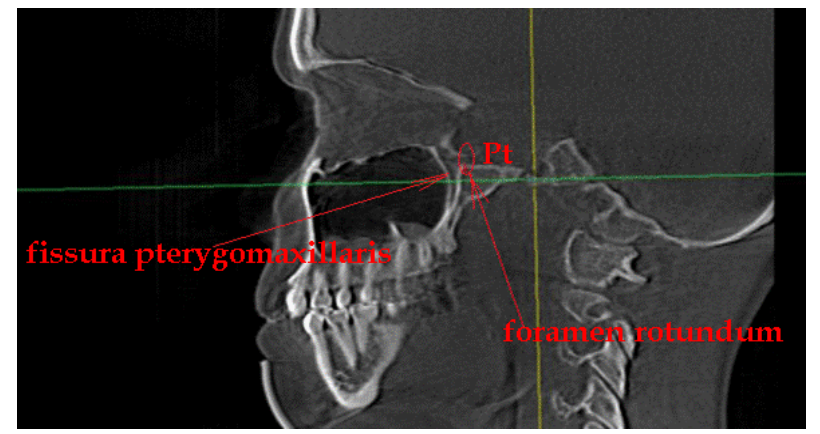

Figure 4. Point Pt on saggital section.

Point condylon (Co) is the highest point of articular head. Before its placement it is necessary to centre the position of mandible in axial opening in order that transverse horizontal axis passing through centers of articular heads is placed in one plane. In order to find $\mathrm{Co}$, it is necessary to displace saggital axis to the centre of articular head, in coronal opening the level of section is displaced to the upper edge of articular head and point Co should be placed in saggital window.

Porion (Po) is one of points, which is difficult to define on classic teleroentgenogram, because it is poorly visualized. It is situated on the upper edge of outer auditory passage.

In order to find it in saggital window one should find the section on which there is osseous basis of outer auditory passage. Usually, this section corresponds to the section on which point Co is established (Figure 5).

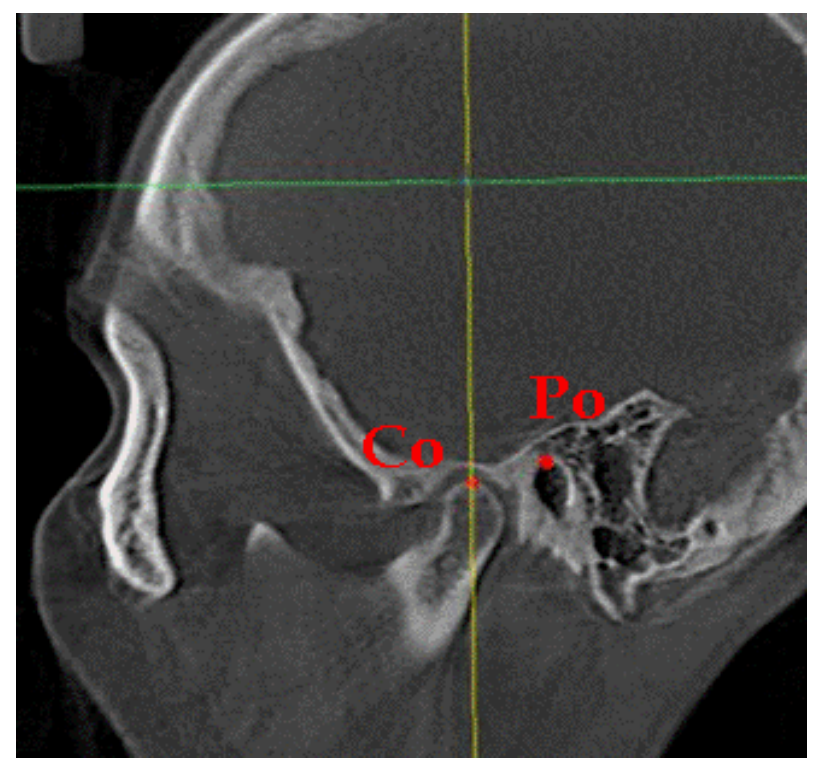

Figure 5. Points Co and Po on saggital section.
In 3D reconstruction the image is transferred in MIP-regimen - projection of maximal intensity on which all previously disturbed points are seen. It is necessary to distribute the level for further definition of lineal parameters.

One takes screenshot and opens it in program «AudaxCeph» (Figure 6).

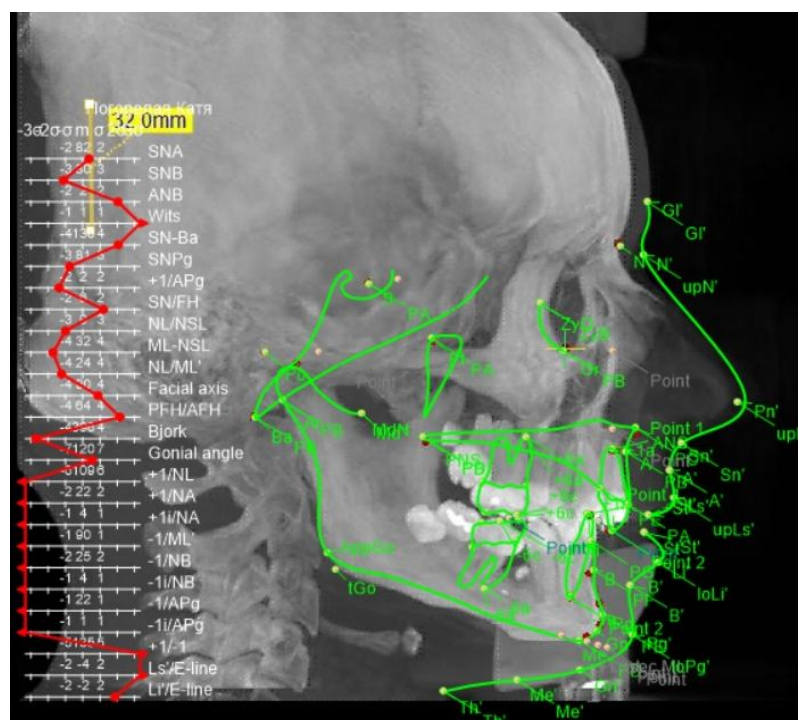

Figure 6. Cephalometry of $3 D$ reconstruction in program "AudaxCeph».

Results. On 3D film in MIP-regimen one can see that some points such as $\mathrm{S}, \mathrm{Ba}, \mathrm{A}, \mathrm{B}, \mathrm{Pt}, \mathrm{Po}$, Co, PNS are impossible to put not using the algorithm of multiple points' distribution.

Soft tissue structures are well visualized in 3D window. CBCT is the way to use points on soft tissues to study parameters of cephalometry will not be correct. In such cases methods of nasal shoulder should be used.

In table 1 results of cephalometry are presented which are done on classic teleroentgenogram and $3 \mathrm{D}$ reconstructions and films received from the same patients.

Comparing all indices at teleroentgenogram and 3D reconstructions, statistically significant difference has not revealed ( $p>0,05)$.

Results of investigation have determined that mistakes of medial index have been indicated during the study of incisive indices $+1 / \mathrm{NL}, 110 \pm 2,72$ and $110,2 \pm 5,02$ correspondingly and also interincisal angle $+1 /-1-133,8 \pm 2,21$ and $138 \pm 5,79$. But such indices were acceptable.

It can be explained by such factors: statistical small amount of investigation; orthodontic - teleroentgenogram and 3D reconstructions of patients with $1^{\text {st }}$ and $3^{\text {rd }}$ of malocclusion were studied, and it affects the variability of distribution of incisors angulation; methodical one contains the different approach of distribution of incisive points. 
Comparison of indices of cephalometric parameters of teleroentgenogram and $3 D$ reconstructions

\begin{tabular}{|c|c|c|c|}
\hline Parameters & Teleroentgenogram & 3D reconstructions & P-index \\
\hline SNA & $81,6 \pm 0,45$ & $83,2 \pm 0,83$ & $\mathrm{p}>0,05$ \\
\hline SNB & $82,2 \pm 1,48$ & $82,4 \pm 1,24$ & $\mathrm{p}>0,05$ \\
\hline ANB & $-0,4 \pm 1,34$ & $0,72 \pm 1,47$ & $\mathrm{p}>0,05$ \\
\hline SN-Ba & $129,4 \pm 1,65$ & $130,8 \pm 1,69$ & $\mathrm{p}>0,05$ \\
\hline ML-NSL & $29,6 \pm 2,05$ & $28,46 \pm 1,68$ & $\mathrm{p}>0,05$ \\
\hline NL-ML & $25,8 \pm 1,87$ & $22,8 \pm 2,18$ & $\mathrm{p}>0,05$ \\
\hline Facial axis & $96,6 \pm 1,68$ & $94,6 \pm 1,76$ & $\mathrm{p}>0,05$ \\
\hline$<\mathrm{G}$ & $125 \pm 0,4$ & $124,4 \pm 0,27$ & $\mathrm{p}>0,05$ \\
\hline$+1 / \mathrm{NL}$ & $110 \pm 2,72$ & $110,2 \pm 5,02$ & $\mathrm{p}>0,05$ \\
\hline$-1 / \mathrm{ML}$ & $89,2 \pm 2,06$ & $86,8 \pm 1,12$ & $\mathrm{p}>0,05$ \\
\hline$+1 /-1$ & $133,8 \pm 2,21$ & $138 \pm 5,79$ & $\mathrm{p}>0,05$ \\
\hline
\end{tabular}

On classic films of teleroentgenogram there is overlapping of the frontal part of teeth and it is necessary to find the medial position of points or incisive points of the most protruding incisor, especially in the apex. Based on data of investigations to $75 \%$ of cases apical points can't be localized [13]. Often mistakes are connected if lateral incisors are situated labialy than laterally and also at crowding.

Incisive points can be definitely determined by displacement of medial and saggital line right and left on 3D reconstructions.

Also, CBCT gives an opportunity to define the position of points not only in anterior teeth, but also anglution in lateral region.

So, it should be considered 3D cephalometric analysis should be reliable method like TRG cephalometric analysis, however its informative value is higher.

Conclusions. 3D cephalometric analysis is reliable method of diagnostics as traditional one.

CBCT (cone-beam computerized tomography) is more prone to diagnostics of difficult orthodontic abnormalities, for example when impacted teeth, embedded teeth, congenital pathologies, and syndrome abnormalities are present or before the next dental implantation process.

CBCT can be the best way among all X-ray methods of investigation complimented by decrease radiation exposure on patient and above mentioned advantages.

\section{References}

1. Phulari BS. An Atlas on Cephalometric Landmarks. Jaypee Brothers Medical Pub.2013:213.

2. Novomodnyih LC. Raschet $i$ analiz trg $v$ praktike vracha-ortodonta. X-Ray Art.2012;1:34-36.

3. Adams GL, Gansky SA, Miller A, Harrell WE, Hatcher DC. Comparison between traditional 2dimensional cephalometry and a 3-dimensional approach on human dry skulls. Am J Orthod Dentofacial Orthop. 2004;126:397-409.

4. Lagrave're MO, Major PW. Proposed reference point for 3- dimensional cephalometric analysis with cone-beam computerized tomography. Am J Orthod Dentofacial Orthop.2005;128:657-660.

5. Kuroedova VD, Vyzhenko EE, Stasiuk AA, Makarova AN. Optical density of mandible in orthodontic patients. Wiadomości Lekarskie. 2018; 120(6):1161-1164.

6. Kuroyedova VD., Stasyuk AA, , Vyzhenko EE., Makarova AN, Sokolohorska-Nykina YK. The study of temporomandibular joint in dentofacial abnormalities using cone beam computed tomography. The New Armenian Medical Journal.2018;4:71-75.

7. Lagrave're MO, Hansen L, Harzer W, Major PW. Plane orientation for standardization in 3dimensional cephalometric analysis with com puterized tomography imaging. Am J Orthod Dentofacial Orthop. 2006;129:601-614

8. Papadopoulos MA, Jannowitz C, Boettcher $P$, Henke J, Stolla R, Zeilhofer HF, et al. Threedimensional fetal cephalometry: anevaluation of the reliability of cephalometric measurements based on three-dimensional CT reconstructions and on dry skulls of sheep fetuses. J Craniomaxillofac Surg.2005;33:229-237.

9. Novomodnyih L.S 3D-tsefalometriya i dlya chego ona nuzhna?. X-Ray Art. 2014;4:66-67.

10. Silva MA, Wolf $U$, Heinicke $F$, Bumann A, Visser $H$, Hirsch E. Conebeam computed tomography for routine orthodontic treatment planning: a radiation dose evaluation. Am J Orthod Dentofacial Orthop. 2008; 133:640.

11. Halazonetis DJ. From 2-dimensional cephalograms to 3-dimensional computed tomography scans. Am J Orthod Dentofacial Orthop. 2005;127:627-637.

12. Kırzıoglu Z, Karayılmaz H, Baykal B. Value of computed tomography (CT) in imaging the morbidity of submerged molars: a case report. Eur J Dent. 2007; 1:246-250.

13. Ludlow JB, Davies-Ludlow LE, White SC. Patient risk related to common dental radiographic examinations: the impact of 2007 International Commission on Radiological Protection recommendtions regarding dose calculation. J Am Dent Assoc. 2008;139:237-243.

Стаття надійшла: 30.10.2019 p. 


\section{Резюме}

Стаття присвячена особливостям розстановки точок в ортодонтії та вивченню цефалометричних параметрів на 3D-реконструкціях.

Мета дослідження - розробити алгоритм розстановки основних цефалометричних точок на 3Dреконструкції, отриманій із КЛКТ, і дати порівняльну характеристику вимірювань, проведених на класичних TPГ і на 3D-реконструкції.

Матеріали і методи. Для порівняння було взято основні кутові скелетні сагітальні параметри (SNA, SNB, ANB, SN-Ba), вертикальні (ML-NSL, NL-ML, Facial axis, <G) і дентальні (+1/NL, -1/ML, +1/-1). Аналіз знімків проводили в програмі для цефралометрії «AudaxCeph». Усього досліджено TPГ і 3Dреконструкцій 20 пацієнтів.

Порівнюючи всі значення при аналізі ТРГ і 3D- реконструкцій, статистично достовірної різниці не виявлено ( $p>0,05)$. Найбільші показники розкиду помилки середнього $(\mathrm{m})$ встановлені при вивченні

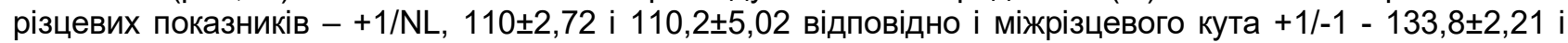
$138 \pm 5,79$.

Ключові слова: цефалометрія, телерентгенографія, конусно-променева комп'ютерна томографія, зубощелепна аномалія.

\section{Резюме}

Данная статья посвящена особенностям расстановки точек в ортодонтии и изучению цефалометрических параметров на 3D-реконструкциях.

Цель исследования - разработать алгоритм расстановки основных цефралометрических точек на 3D-реконструкции, полученной из КЛКT, и дать сравнительную характеристику измерений, проведенных на классических TPГ и на 3D-реконструкции.

Материалы и методы. Для сравнения были взяты основные угловые скелетные сагиттальные параметры (SNA, SNB, ANB, SN-Ba), вертикальные (ML-NSL, NL-ML, Facial axis, <G) и дентальные (+1/NL, -1/ML, +1/-1). Анализ снимков проводили в программе для цефалометрии «AudaxCeph». Bcero исследовано ТPГ и 3D-реконструкций 20 пациентов.

Сравнивая все значения при анализе TPГ и 3D- реконструкций, статистически достоверной разницы не выявлено ( $>$ > 0,05). Самые высокие показатели разброса ошибки среднего (m) установлены

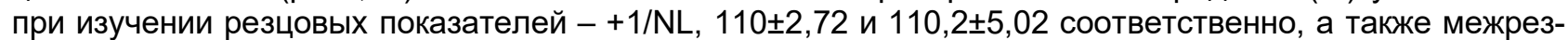
цового угла +1/-1 - 133,8 $\pm 2,21$ и $138 \pm 5,79$.

Ключевые слова: цефалометрия, телерентгенография, конусно-лучевая компьютерная томография, зубочелюстная аномалия.

\section{Summary}

This article is concerned with peculiarities of points' placement in orthodontics and study of cephalometric parameters on $3 \mathrm{D}$ reconstructions.

The aim of the investigation is to develop out the algorithm of distribution of main cephalometric points on $3 \mathrm{D}$ reconstructions, received from $\mathrm{CBCT}$ and compare characteristics of measurements done on classic teleroentgenogram (TRG) and 3D reconstructions.

Materials and methods. The main angular (SNA, SNB, ANB, SN-Ba) skeletal saggital parameters, vertical (ML-NSL, NL-ML, Facial axis, $<G)$, and dental were taken $(+1 / \mathrm{NL},-1 / \mathrm{ML},+1 /-1)$. The analysis of dental radiographs was done for cephalometry «AudaxCeph». Teleroentgenogram and 3 D reconstructions of 20 patients were investigated.

Comparing all indices of TRG and 3D reconstructions statistically significant difference was not revealed $(p>0,05)$. The most significant indices was established during the study of incisive indices $-+1 / \mathrm{NL}, 110 \pm 2,72$ и 110,2 $\pm 5,02$ correspondingly inter-incisal angle $+1 /-1-133,8 \pm 2,21$ and $138 \pm 5,79$.

Key words: cephalometry, teleroentgenogram (TRG), cone-beam computerized tomography (CBCT), malocclusion. 